\title{
Politik Hukum Pengelolaan Zakat Di Indonesia
}

\author{
Muhammad Ramli \\ Magister Hukum Fakultas Hukum Universitas Islam Indonesia Yogyakarta Indonesia \\ Jln. Cik Di Tiro No. 1 Yogyakarta Indonesia \\ ramlimuhammad1788@gmail.com
}

\begin{abstract}
This study aims to identify and describe: first, the legal politics of zakat management in Indonesia to alleviate poverty; second, the formulation of zakat management in Indonesia to alleviate poverty. This is a normative juridical research type. The results of this study conclude that first, the legal politics of zakat management in Indonesia through the law on zakat management fails to support the national zakat structure which encourages acceleration of poverty alleviation and improvement of welfare and is oriented towards making people who are entitled to receive zakat turn into people who are obliged to pay zakat based on increase in zakat funds collected. Second, the formulation of zakat management in Indonesia is included in the category of partial model or voluntary system, where the state already has a legal basis or formal rules governing zakat, but has not made zakat an obligation that must be fulfilled by citizens. The formulation of future zakat management must be managed with a comprehensive model.
\end{abstract}

Key Word: Formulation; legal politics; poverty alleviation; zakat management

\begin{abstract}
Abstrak
Penelitian ini bertujuan untuk menemukan dan mendeskripsikan tentang: pertama, politik hukum pengelolaan zakat di Indonesia untuk mengentasan kemiskinan; kedua, formulasi pengelolaan zakat di Indonesia untuk mengentasan kemiskinan. Penelitian yang dilakukan adalah jenis penelitian yuridis normatif. Hasil penelitian ini menyimpulkan, pertama, politik hukum pengelolaan zakat di Indonesia melalui undang-undang tentang pengelolaan zakat gagal mendukung struktur zakat nasional yang mendorong akselerasi pengentasan kemiskinan dan peningkatan kesejahteraan serta berorientasi pada menjadikan orang yang berhak menerima zakat berubah menjadi orang yang berkewajiban membayar zakat berdasarkan meningkatnya dana zakat yang terkumpul. Kedua, formulasi pengelolaan zakat di Indonesia masuk dalam kategori model parsial atau voluntary system, dimana negara telah memiliki dasar hukum atau aturan formal yang mengatur zakat, namun belum menjadikan zakat sebagai kewajiban yang harus ditunaikan warga negara. Formulasi pengelolaan zakat masa yang akan datang harus dikelola dengan model komprehensif.
\end{abstract}

Kata-kata Kunci: Politik hukum; formulasi; pengelolaan zakat; pengentasan kemiskinan 


\section{Pendahuluan}

Pasal 29 ayat (2) UUD 1945 menyebutkan bahwa negara menjamin kemerdekaan tiap-tiap penduduk untuk memeluk agamanya masing-masing dan untuk beribadat menurut agama dan kepercayaannya itu. Kata "menjamin" sebagaimana termaktub dalam pasal tersebut bersifat keharusan, yang berarti negara berkewajiban secara aktif melakukan upaya-upaya agar tiap-tiap penduduk dapat memeluk agama dan beribadat menurut agama dan kepercayaannya. ${ }^{1}$

Berkenaan dengan hal tersebut, secara faktual hukum Islam menjadi sumber hukum bagi pembentukan sistem hukum nasional, di samping hukum barat dan hukum adat. Nilai-nilai yang terkandung dalam hukum Islam telah mewarnai hukum yang berlaku di Indonesia, termasuk undang-undang tentang pengelolaan zakat. Zakat merupakan salah satu kekuatan ekonomi umat yang sudah teruji sepanjang sejarah, sehingga banyak negara-negara Islam mengakomodasi regulasi zakat sebagai hukum positif dalam peraturan perundang-undangan negara. ${ }^{2}$

Kebijakan Khalifah Abu Bakar memerangi mereka yang menolak membayar zakat, menjaga karakter politik zakat, yaitu zakat harus diserahkan kepada negara untuk dikelola. ${ }^{3}$ Sebagaimana awal surat at-Taubah ayat 103 : (Ambilah zakat dari harta mereka), jumhur ulama sepakat bahwa perintah tersebut ditujukan kepada Nabi Muhammad dan pada setiap orang yang mengurus urusan kaum muslimin sesudahnya. ${ }^{4}$

Zakat yang semula hanya sekedar amal karitas, mulai bertransformasi menjadi kekuatan ekonomi-sosial yang diperhitungkan. Meski demikian potensi yang besar ini tetap tidak mendapat perhatian yang memadai dari pemerintah. ${ }^{5}$ Titik balik terpenting dunia zakat nasional terjadi pada 1999 dengan diundangkannya UndangUndang Nomor 38 Tahun 1999 tentang Pengelolaan Zakat dan diamandemen menjadi Undang-Undang Nomor 23 Tahun 2011 tentang Pengelolaan Zakat. ${ }^{6}$

Indonesia dengan jumlah penduduk sekitar 270,2 juta jiwa, sekitar 26,42 juta penduduk Indonesia masih hidup di bawah garis kemiskinan.7 Kemiskinan dan ketimpangan pendapatan masih menjadi masalah utama yang dihadapi oleh

\footnotetext{
${ }^{1}$ Agustianto, "Politik Hukum Ekonomi Syariah", dalam http://www.agustiantocentre.com/?p=450, diakses 27 Agustus 2020, pukul 20.00 WIB.

${ }^{2}$ Amran suadi dan Mardi Candra, Politik Hukum: Perspektif Hukum Perdata dan Pidana Islam serta Ekonomi Syari'ah, Edisi Pertama, Kencana, Jakarta, 2016, hlm. 282.

3 http://www.ibnukatsironline.com/2015/05/tafsir-surat-at-taubah-ayat-103-104.html, diakses 10 April 2021, pukul 08.00 WIB.

${ }^{4}$ Yusuf Al-Qardawi, Fiqh al-Zakah, diterjemahkan oleh Salman Harun, Didin Hafidudin, Hasanudin. Cetakan Kedua Belas, Pustaka Litera Antar Nusa, Bogor, 2007, hlm. 545-546.

${ }^{5}$ Yusuf Wibisono, Mengelola Zakat Indonesia "Diskursus Pengelolaan Zakat Nasional dari Rezim Undang-Undang Nomor 38 Tabun 1999 ke Rezim Nomor 23 Tahun 2011”, Prenadamedia Group, Jakarta, 2015, hlm. 43-44.

${ }^{6}$ Ibid., hlm. 43.

7 https://www.bps.go.id/website/images/Profil-Kemiskinan-di-Indonesia-September-2020-ind.jpg, diakses 22 Maret 2021, pkl 21.00 WIB.
} 
bangsa Indonesia. Para akademisi berpendapat bahwa pembangunan ekonomi di suatu negara telah menciptakan sebuah pilihan di antara pertumbuhan ekonomi dan distribusi. Pendekatan distribusi konvensional tampaknya gagal dalam mengatasi kedua masalah tersebut. Oleh karena itu, pengenalan mekanisme zakat sangat diperlukan sebagai pendekatan alternatif untuk memecahkan masalah. ${ }^{8}$

Zakat sebagai program penanggulan kemiskinnan wajib (mandatory expenditure) dalam perekonomian Islam, seharusnya memiliki dampak yang signifikan dan berjalan secara otomatis built-in) di dalam sistem Islam. Alasannya adalah alokasi dana zakat sudah ditentukan secara pasti di dalam syariah dimana hanya diperuntukkannya bagi delapan golongan (ashnaf) saja yaitu : fakir, miskin, pengelola zakat, mu'allaf, budak, orang-orang berhutang, fi sabilillah, Ibnu sabil. Hal ini menunjukkan bahwa tujuan utama zakat adalah untuk mengatasi masalah kemiskinan. ${ }^{9}$

\section{Rumusan Masalah}

Berdasarkan uraian dan paparan pada latar belakang masalah di atas, fokus penelitian adalah: Pertama, bagaimana politik hukum pengelolaan zakat di Indonesia untuk mengentasan kemiskinan? Kedua, bagaimana formulasi pengelolaan zakat di Indonesia untuk mengentasan kemiskinan?

\section{Tujuan Penelitian}

Tujuan penelitian ini yaitu pertama, untuk mengkaji secara komprehensif politik hukum pengelolaan zakat di Indonesia untuk mengentasan kemiskinan; Kedua, untuk mengkaji formulasi pengelolaan zakat di Indonesia untuk mengentasan kemiskinan.

\section{Metode Penelitian}

Jenis Penelitian ini adalah yuridis normatif dengan langkah untuk menemukan suatu aturan hukum, prinsip-prinsip hukum, doktrin-doktrin hukum guna menjawab isu hukum yang dihadapi. Objek dalam penelitian ini adalah politik hukum pengeloaan zakat di Indonesia. Teknik pengumpulan bahan hukum yang dilakukan melalui studi pustaka. Pendekatan yang digunakan adalah pendekatan perundang-undangan (statute aprroach) dan pendekatan

\footnotetext{
${ }^{8}$ Firmansyah, “Zakat sebagai Instrumen Pengentasan Kemiskinan dan Kesenjangan Pendapatan”, Jurnal Ekonomi dan Pembangunan, Vol 21 No. 2, (2013), hlm. 179.

${ }^{9}$ Yusuf Al-Qardawi, Hukum..., Op. Cit., hlm. 510.
} 
konseptual (conceptual approach). Selanjutnya hasil penelitian dianalisis secara kualitatif dan dipaparkan dengan bentuk deskriptif analitis. ${ }^{10}$

\section{Hasil Penelitian dan Pembahasan}

\section{Pengelolaan Zakat Masa Rasulullah Sampai Sahabat}

Pada masa Nabi Muhammad, pembayaran zakat diatur dan dikelola langsung oleh Nabi, sebuah peran yang kemudian sering dipahami sebagai legitimasi negara untuk mengatur dan mengelola zakat. Peran ini murni berdasarkan peran politik yang dilakukan oleh Nabi dalam komunitas kecil muslim Madinah saat itu. Persepsi otoritas negara terhadap zakat muncul berdasar dua fakta. Pertama, Nabi Muhammad meminta para sahabatnya untuk mengumpulkan zakat. Tindakan ini dianggap sebagai legitimasi negara dalam pengumpulan zakat (sebagai amil). Kedua, Nabi Muhammad menggunakan dana zakat untuk membiayai beberapa pengeluaran negara, termasuk kampanye militer (perang). Mekanisme ini menunjukkan bahwa zakat sebagai semacam pajak agama yang merupakan hak prerogatif penguasa. ${ }^{11}$

Pada masa keempat Khulafa' Rasyidin pada umumnya mengikuti cara Nabi Muhammad mengelola dan mengatur zakat. ${ }^{12}$ Pemerintah dalam proses ini dapat memerankan diri sebagaimana yang diperankan pemerintahan Khalifah Abu Bakar. Selaku kepala negara Abu Bakar melakukan paksaan terhadap mereka yang tidak mau membayar zakatnya dan terhadap mereka yang tidak mau mendistribusikan zakat yang telah terkumpul.13

\section{Pengelolaan Zakat Awal Kolonial Hingga Reformasi di Indonesia}

Islamisasi terjadi melalui dua cara, yakni melalui kalangan pribumi yang masuk Islam dan muslim pendatang. Pertama, muslim pribumi yang baru masuk Islam belum bisa sepenuhnya mempraktikkan semua ajaran Islam, sedekah dan zakat merupakan ajaran yang dapat mereka terima sejak awal. Kedua, muslim pendatang mempraktikkan sedekah dan zakat sejak awal kehadiran mereka di Nusantara. Sebagian mereka membayar zakat dan fitrah dan memberikannya kepada para tetangga mereka yang membutuhkan dan tradisi pembayaran dikelola melalui masjid. Baik sufi maupun pendakwah, mereka memiliki kecederungan untuk mempraktikkan kemurahan hati secara transedental daripada institusional. ${ }^{14}$

${ }_{10}$ Peter Mahmud Marzuki, Penelitian Hukum Edisi Revisi, Cetakan Ketujuh, Kencana, Jakarta 2015, hlm. 47.

11 Amelia Fauzia, Filantropi Islam "Sejarah dan Kontestasi Masyarakat Sipil dan Negara di Indonesia", Gading Publishing, Yogyakarta, 2016, hlm. 49.

12 Ibid., hlm 51.

13 Amran Suadi dan Mardi Candra, Politik ..., Op. Cit., hlm. 282.

${ }^{14}$ Amelia Fauzia, Filantropi..., Op. Cit., hlm. 71. 
Pada era penjajahan Belanda, zakat sepenuhnya menjadi urusan pribadi. Kebijakan pemerintah kolonial yang netral dengan pendekatan non-intervensi, mengizinkan penguatan masyarakat sipil melalui pendayagunaan zakat untuk pendidikan dan kegiatan sosial lainnya. Pemerintah berupaya membuat zakat mal dan zakat fitrah sepenuhnya menjadi hibah sukarela sehingga tidak membebani rakyat yang sudah menanggung beban pajak yang sangat berat. Zakat dikumpulkan secara sukarela kepada kiai, ajengan dan guru mengaji. ${ }^{15}$

Cikal bakal pengelolaan zakat modern di Indonesia dapat dilihat dari pengelolaan zakat oleh Muhammadiyah, organisasi masyarakat Islam Indonesia terbesar kedua yang berdiri pada 1912. Berbekal tiga landasan utama, yaitu teologi al-Maun (Al-Quran 107: 1-7), moderisme dan etos puritan, Muhammadiyah sejak 1918 telah mampu mentransformasikan zakat dan praktik filantropi Islam lainnya untuk keadilan dan kesejahteraan sosial. Muhammadiyah menganut prinsip nondiskriminasi terhadap agama, kelompok maupun kebangsaan, baik dalam penyaluran maupun penghimpunan dana. Muhammadiyah bahkan menerima subsidi dan bantuan dari pemerintah kolonial Belanda. ${ }^{16}$

Kebijakan Orde Lama adalah netralitas negara terhadap urusan agama warga negara dan hanya memfasilitasi kehidupan beragama tanpa terlibat dalam pengelolaana praktik keagamaan. Pada 1950-an, identitas keagamaan tidak cukup kuat untuk mendukung pelaksanaan gerakan zakat dan praktik Islam lainnya. Namun bukan berarti praktik zakat lenyap. Awal rezim Orde Baru, mulai muncul keinginan agar pemerintah terlibat dalam pengelolaan zakat dalam rangka mengoptimalkan. ${ }^{17}$

Pasca runtuhnya rezim Orde Baru, jumlah organisasi pengelola zakat meningkat drastis. Pertumbuhan lembaga filantropi Islam Indonesia di era reformasi ini banyak dimotivasi oleh empat faktor internal, yaitu euforia gerakan reformasi, krisis ekonomi, konflik etnis dan agama, dan bencana tsunami pada akhir 2004 di Aceh. Kondisi ekternal seperti solidaritas terhadap Muslim Afghanistan, Palestina dan Irak, memicu kelahiran lembaga filantropi Islam di Indonesia. ${ }^{18}$

Titik balik terpenting dunia zakat nasional terjadi pada 1999 terbentuknya Undang-Undang Nomor 38 Tahun 1999 tentang Pengelolaan Zakat merupakan kontribusi utama Departemen Agama (Depag) dan kemudian diikuti FOZ dalam proses legislasi, meskipun Depag berusaha mendominasi proses legislasi. Amandemen yang dilakukan pada 2011 melahirkan Undang-Undang Nomor 23 Tahun 2011 tentang Pengelolaan Zakat yang pengelolaan zakatnya di sentralisasi

\footnotetext{
15 Yusuf Wibisono, Mengelola ..., Op. Cit, hlm. 36.

16 Amelia Fauzia, Filantropi ..., Op. Cit., hlm. 156-166.

17 Ibid., hlm. 186- 190.

18 Amelia Fauzia, Filantropi ..., Op. Cit., hlm. 225-228.
} 
di tangan pemerintah, yaitu melalui BAZNAS. ${ }^{19}$ Perkembangannya, pengelolaan zakat bukan hanya sebatas pelaksana kewajiban keagamaan, sudah lebih kepada pemberdayaan institusi keuangan publik, sehingga zakat lebih berhasil guna, berdaya guna, dan dapat dipertanggungjawabkan secara amanah, adil, dan transparan. ${ }^{20}$

\section{Pengentasan Kemiskinan}

Arti pengetasan dalam Kamus Besar Bahasa Indonesia (KBBI) adalah proses, cara, perbuatan mengentas atau mengentaskan. Sedangkan mengentaskan adalah memperbaiki (menjadikan, mengangkat) nasib atau keadaan yang kurang baik kepada yang lebih baik. ${ }^{21}$ Kemiskinan adalah keadaan penduduk atau sebagian penduduk tidak berharta atau serba kekurangan (berpenghasilan sangat rendah) yang hanya dapat memenuhi kebutuhan makanan, pakaian dan perumahan yang sangat diperlukan untuk mempertahankan tingkat kehidupan yang minimum.22 Pengentasan kemiskinan dapat diartikan sebagai proses atau cara memperbaiki nasib orang-orang yang tidak mempunyai apa-apa menjadi mempunyai apa-apa dalam memenuhi kehidupan sehari-hari.

Ibnu al-Arabi berpendapat, sama saja antara fakir dan miskin yaitu orangorang yang tidak mempunyai apa-apa. Pendapat lain diutarakan M. Ali Hasan, melihat fakir dan miskin dari segi keperluan mereka, siapa yang lebih pantas didahulukan dan jangan terlalu kaku berpegang pada istilah. Pada suatu saat bila masyarakat sudah makmur dan kebutuhan pokok semuanya sudah merata, maka pengertian fakir dan miskin bisa berubah. Umpamanya, sekiranya pada umumnya anggota masyarakat sudah mampu membeli motor atau TV berwarna, maka yang dianggap fakir dan miskin adalah orang yang belum mampu membeli motor atau TV berwarna. ${ }^{23}$

Pengentasan kemiskinan harus adanya perubahan yang semuanya sangat tergantung kepada kemampuan perekonomian dan ada kemauan dari semua pihak, untuk memerangi kemiskinan. Cara memerangi kemiskinan salah satunya dengan zakat, di samping cara lain, seperti infak, sedekah dan lain-lain yang semuanya ditujukan untuk menghapus kemiskinan. Zakat adalah salah satu solusi efektif untuk membangun umat dengan memberdayakan zakat sebagai salah satu potensi umat Islam yang harus dikembangkan secara maksimal baik

\footnotetext{
${ }^{19}$ Ibid., hlm. 47.

${ }^{20}$ Rahmani Timorita Yulianti, Good Corporate Governance di Lembaga Zakat, Kaukaba Dipantara, Yogyakarta, 2015, hlm. 50 .

${ }^{21}$ https://kbbi.kemdikbud.go.id/entri/pengentasan, diakses 22 Mei 2021, pukul 21.48 WIB.

22 https://kbbi.web.id/kemiskinan, diakses 13 Juni 2021, pukul 01.22 WIB.

23 M. Ali Hasan, Zakat dan Infak: Salab Satu Solusi Mengatasi Problema Sosial di Indonesia, Cetakan Ketiga, Prenamedia Group, Jakarta, 2015, hlm. 94.
} 
zakat fitrah maupun zakat harta. Zakat salah satu instrumen disebutkan AlQuran sebagai upaya dalam memerangi kemiskinan tersebut. Harta yang ada setiap orang kaya, dalam Islam diakui bahwa ada bagian orang miskin di dalamnya. Zakat adalah alat distribusi untuk pemerataan harta dari the have (orang kaya) kepada the have not (orang miskin). ${ }^{24}$

\section{Politik Hukum Pengelolaan Zakat di Indonesia}

Politik hukum menurut Moh. Mahfud MD adalah legal policy atau garis (kebijakan) resmi tentang hukum yang akan diberlakukan baik dengan membuat hukum baru maupun dengan penggatian hukum lama, dalam rangka mencapai tujuan negara. Dengan demikian politik hukum merupakan pilihan tentang hukum-hukum yang akan diberikan sekaligus pilihan tentang hukum-hukum yang akan dicabut atau tidak diberlakukan yang kesemuanya dimaksudkan untuk mencapai tujuan negara seperti tercantum dalam pembukaan UUD 1945.25

Politik hukum adalah proses pembentukan dan pelaksanaan sistem atau tatanan hukum yang mengatur kehidupan masyarakat dalam negara secara nasional. Jadi pengertian politik hukum tidak hanya mengandung makna pembentukan hukum melalui pembentukan peraturan perundang-undangan (legal substance) sebagaimana dipahami selama ini, namun juga dalam arti penguatan para penegak hukum dan sarana penegakan hukum (legal structure) serta pembangunan budaya hukum. ${ }^{26}$

Berdasar hal tersebut, maka seluruh komponen dan unsur-unsur sistem hukum nasional harus dibangun secara simultan, sinkron dan terpadu agar sistem hukum nasional yang holistik dan komprehensif yang berdasarkan filsafat Pancasila dan jiwa UUD 1945 serta akan terpenuhi kepentingan dan kebutuhan masyarakat Indonesia di masa akan datang. ${ }^{27}$

Lahirnya undang-undang peraturan perundang-undangan tentang pengelolaan zakat mengubah paradigma tata kelola zakat dalam bentuk kepanitian menjadi tata kelola lembaga. Zakat yang awal hanya dikelola dengan pembentukan panitia seadanya dan hanya penyaluran saja, namun zakat saat ini dikelola lebih terorganisir dan dapat dinikmati tidak hanya pada momen Ramadhan tetapi juga dapat dirasakan sepanjang bulan, sepanjang tahun dan dapat dirasakan manfaatnya oleh orang-orang yang berhak menerima zakat (fakir dan miskin, amil zakat, mualaf, budak, orang berhutang, fi sabilillah dan ibnu sabil).

\footnotetext{
${ }^{24}$ Nurul Huda et.al., Zakat...., Op. Cit., hlm. 111.

${ }^{25}$ Moh. Mahfud MD, Politik Hukum di Indonesia, Cetakan Kelima, Rajawali Pers, Jakarta, 2012, hlm. 1.

26 Otong Rosadi dan Andi Desmon, Studi Politik Hukum : Suatu Optik Ilmu Hukum, Thafa Media, Yogyakarta, 2013, hlm. 4-6.

${ }^{27}$ Ibid., hlm. 90.
} 
Hal tersebut sebenarnya sejalan dengan Pasal 34 ayat (1) UUD 1945 menentukan, "Fakir miskin dan anak terlantar dipelihara negara". ${ }^{28}$ Pemeliharaan adalah tindakan aktif, tetapi kata ini dikaitkan dengan tindakan oleh negara. Karena itu, yang memelihara itu bukan hanya pemerintah, tetapi juga DPR sebagai lembaga legislatif penentu kebijakan dalam bentuk Undang-Undang. Pemerintah menjalankan tugas pemeliharaan fakir, miskin dan anak terlantar itu tergantung kepada apa yang diatur oleh undang-undang. Karena itu, yang pertama harus dipastikan adalah pengaturan dalam undang-undangnya harus benar-benar mencerminkan perintah konstitusi agar fakir, miskin dan anak terlantar dapat diperlihara dengan baik. ${ }^{29}$

Praktiknya, tidak mungkin semua orang fakir, miskin dan anak terlantar diperlihara oleh institusi atau badan-badan atau petugas-petugas pemerintah. Negara (lembaga legislatif dan eksekutif) harus mengatur kegiatan pemelihraan fakir, miskin dan anak terlantar itu dengan peraturan perundang-undangan sebagaimana mestinya, pemerintah juga harus menetapkan kebijakan-kebijakan operasional yang menjamin agar fakir, miskin dan anak terlantar dapat dipelihara. ${ }^{30}$ Seperti halnya dibentuknya lembaga zakat yang jelas arah tujuannya menjadi salah satu instrumen untuk memelihara fakir, miskin dan anak terlantar agar terentaskan dari kemiskinan.

Undang-Undang Nomor 38 Tahun 1999 sebagai kerangka regulasi dan institusional untuk dunia zakat nasional, masih jauh dari memadai. Kinerja nasional masih jauh dari optimal. Potensi dana zakat yang sangat besar belum mampu tergali secara optimal dan belum signifikan mengangkat kesejahteraan kelompok miskin di negeri ini. Selain itu, terdapat permasalahan dalam pengelolaan zakat yang efektif transparan dan akuntabel. ${ }^{31}$

BAZNAS Pusat yang seharusnya berperan aktif dalam fungsi pembinaan dan pengawasan sebagai wakil Kementerian Agama untuk pengelolaan zakat belum menjalankan fungsinya dengan baik. Seharusnya BAZNAS Pusat hanya berperan sebagai regulator pengelolaan zakat nasional. Sehinggas BAZNAS Pusat menjadi lembaga yang terhindar dari konflik kepentingan (conflict of interest). Pada kenyataannya, selain berperan sebagai regulator, saat ini BAZNAS Pusat juga berperan sebagai operator yang menjadikan fungsi penghimpunan, pengelolaan, dan pendayagunaan dana zakat. ${ }^{32}$

\footnotetext{
28 Pasal 34 ayat (1) Undang-Undang Dasar 1945.

${ }^{29}$ Jimly Asshidiqie, Konstitusi Ekonomi, Cetakan Kedua, Kompas, Jakarta, 2016, hlm. 281.

${ }^{30}$ Ibid., hlm. 282.

31 Yusuf Wibisono, Mengelola ..., Op. Cit., hlm. 49.

${ }^{32}$ Nurul Huda, et.al., Zakat ..., Op. Cit., hlm. 50.
} 
Kondisi Indonesia saat ini masih dihadapkan pada kondisi riil dengan masih banyaknya masyarakat miskin. Negaralah yang harus bertanggungjawab terhadap kemiskinan, kelaparan, keterbelakangan dan jaminan masa tua bagi semua warga negara. Kenyataan yang dihadapi dan dirasakan oleh kita sebagai warga negara Indonesia adalah bahwa negara belum sepenuhnya mampu memberikan perlindungan terhadap warganya. Meminjam istilah Adam Smith, bahwa tugas negara harus memenuhi, pertama, negara berkewajiban memberikan rasa aman terhadap segala ancaman dalam bentuk apapun bagi semua warga negara; dan kedua, negara juga mendorong dan menciptakan kesejahteraan ekonomi bagi semua warga. ${ }^{33}$

Tiga program pengentasan kemiskinan yang dilakukan pemerintah saat ini, yakni: pertama, stabilitas harga, bila harga bahan pokok naik artinya juga garis kemiskinan akan naik dan biaya hidup penduduk miskin akan naik; kedua, program subsidi dan dana desa, agar program-program kementerian terutama pertanian, UMKM, dan penyaluran dana desa betul-betul bisa menjangkau 40 persen penduduk lapisan; dan ketiga, program-program bantuan sosial seperti Kartu Indonesia Pintar, Kartu Indonesia Sehat, Program Keluarga Harapan, kemudian beras sejahtera bisa disalurkan tepat sasaran dan tepat waktu sehingga bisa meringankan beban hidup masyarakat miskin. ${ }^{34}$

Program yang telah tercanangkan oleh pemerintah yang bertujuan pada pengentasan kemiskinan disandingkan dengan data jumlah dan presentase penduduk miskin dari berita resmi statistik profil kemiskinan di Indonesia dari 2015 sampai dengan Maret 2020 dan Pengumpulan dan Penyaluran Zakat 2015 2020 khusus asnaf fakir miskin dari Outlook Zakat Indonesia 2020, bertujuan untuk mengetahui seberapa besar fungsi zakat dalam pengentasan kemiskinan di Indonesia.

Tabel 3. Jumlah dan Presentase Penduduk Miskin, Maret 2015 - Maret 2020

\begin{tabular}{cccc}
\hline Tahun & Bulan & Jumlah & Presentase \\
\hline \multirow{2}{*}{2015} & Maret & 28,59 Juta & $11,22 \%$ \\
& September & 28,51 Juta & $11,13 \%$ \\
\multirow{2}{*}{2016} & Maret & 28,01 Juta & $10,86 \%$ \\
\multirow{2}{*}{2017} & September & 27,76 Juta & $10,7 \%$ \\
& Maret & 27,77 Juta & $10,64 \%$ \\
\multirow{2}{*}{2018} & September & 26,58 Juta & $10,12 \%$ \\
& Maret & 25,95 Juta & $9,82 \%$ \\
& September & 25,67 Juta & $9,66 \%$ \\
\hline
\end{tabular}

${ }^{33}$ Ibid., hlm. 12.

34 https://tirto.id/jokowi-bahas-tiga-program-pengentasan-kemiskinan-ctqT, diakses 7 Juni 2021, pkl 17.20 WIB. 


\begin{tabular}{lcll}
\hline & & & \\
2019 & Maret & 25,14 Juta & $9,41 \%$ \\
2020 & September & 24,79 Juta & $9,22 \%$ \\
& Maret & 26,42 Juta & $9,78 \%$ \\
\hline
\end{tabular}

Sumber: Berita Resmi Statistik Profil Kemiskinan di Indonesia Maret 2020

Tabel 4. Pengumpulan dan Penyaluran Zakat 2015 - 2020

\begin{tabular}{crrr}
\hline Tahun & \multicolumn{1}{c}{ Pengumpulan } & \multicolumn{1}{c}{ Penyaluran } & Asnaf Fakir Miskin \\
\hline 2015 & $3.500 .000 .000 .000,00$ & $2.200 .000 .000 .000,00$ & $3.700 .000,00$ \\
2016 & $5.000 \mathrm{~s} .000 .000 .000,00$ & $2.900 .000 .000 .000,00$ & $6.090 .000,00$ \\
2017 & $6.200 .000 .000 .000,00$ & $4.800 .000 .000 .000,00$ & $4.700 .000,00$ \\
2018 & $8.100 .000 .000 .000,00$ & $6.800 .000 .000 .000,00$ & $5.520 .000,00$ \\
2019 & $10.100 .000 .000 .000,00$ & $8.100 .000 .000 .000,00$ & $4.520 .000,00$ \\
2020 & $12.700 .000 .000 .000,00$ & $10.000 .000 .000 .000,00$ & $4.400 .000,00$ \\
\hline
\end{tabular}

Sumber: Outlook Zakat Indonesia 2020

Grafik 2. Jumlah Masyarakat Miskin dan Asnaf Fakir 2015 - 2020

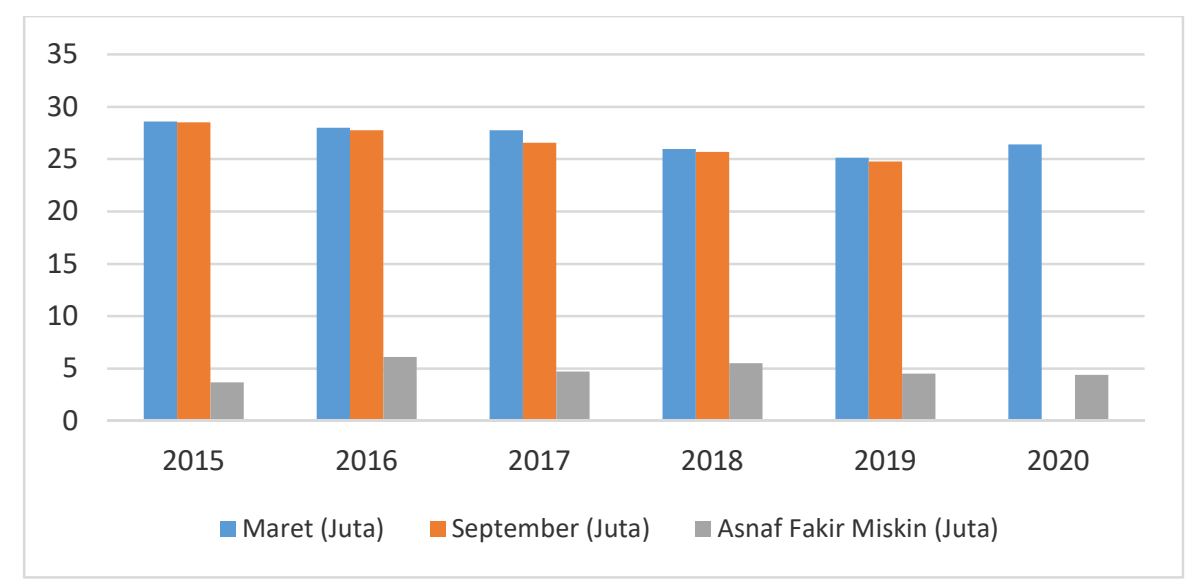

Sumber: Berita Resmi Statistik Profil Kemiskinan di Indonesia Maret 2020 dan Outlook Zakat Indonesia 2020

Data di atas menunjukan naik turun jumlah penduduk miskin, program pengentasan kemiskinan yang dilakukan pemerintah belum bisa memberikan penurunan yang signifikan, dan bahkan di 2020 meningkat 1,63 juta orang dibandingkan September 2019.35 Penyaluran zakat 2015-2019 menunjukan asnaf fakir miskin yang dientaskan dari garis kemiskinan versi BPS berdasarkan OPZ menunjukkan peran BAZ dan LAZ penyaluran zakat berdasar data di atas mengalami naik turun jumlah mustahik fakir miskin. Jika pengelolaan zakat dioptimalkan oleh OPZ secara maksimal dan dukungan yang lebih kuat melalui hlm. 2 .

${ }_{35}$ Badan Pusat Statistik, Berita Resmi Statistik: Profil Kemiskinan di Indonesia Maret 2020, BPS, Jakarta 2020, 
kebijakan pemerintah, tentunya zakat akan bisa menjadi alternatif program pengentasan kemiskinan.

Negara memiliki kewenangan tidak terbatas, karena dalam negara kesejahteraan sosial sudah ada pembagian (distribution) kekuasaan dan pemisahan (separation) kekuasaan yaitu negara memiliki freisess ermessen, yaitu kebebasan untuk turut serta dalam seluruh kegiatan sosial politik dan ekonomi dengan tujuan akhir menciptakan kesejahteran umum (bestuurszorg). ${ }^{36}$ Kesejahteraan umum adalah suatu kondisi tertentu yang dirasakan oleh publik mengenai kehidupannya yang baik dan berkeadilan. Kondisi publik yang sejahtera dapat dideskripsikan sebagai keadaan masyarakat yang bebas dari perasaan lapar, kemiskinan, kecemasan akan hari esok, perasaan takut, dari penindasan dan dari ketidakadilan. ${ }^{37}$

Hal ini merupakan problem besar, di saat warga negara tidak menikmati kesejahteraan. Implikasinya adalah ketidakteraturan sosial (social disorder) akan tampil sebagai konsekuensi dari tidak terpenuhnya kebutuhan dasar tersebut. Mathew Hole menegaskan bahwa kemiskinan sama halnya membiarkan manusia dalam keadaan kacau dan tidak tenang, memerangi kemiskinan adalah suatu tindakan kearifan sipil dan karifan politik. ${ }^{38}$ Faktor penyebab kemiskinan juga bersumber dari distribusi yang tidak merata tidak sama pola kepemilikan sumber daya yang dimiliki itu bisa/dapat menimbulkan ketimpangan distribusi pendapatan atau sumber-sumber. Maka distribusi sumber-sumber pendapatan harus terdistubusikan dengan merata agar masyarakat menerima hak yang sama. ${ }^{39}$

John Rawls menegaskan bahwa, tidak ada keadilan yang diperoleh dengan adanya beberapa situasi individu-individu yang tidak beruntung. Untuk menciptakan kehidupan yang memuaskan, diperlukan adanya skema kerja sama dengan pembagian keuntungan dimana kerja sama tersebut melibatkan semua pihak termasuk mereka yang kurang beruntung. Pertama, sebuah interpretasi atas keadaan saat ini dan permasalahan yang dipilih. Kedua, sebuah pengaturan prinsip. Dalam hal ini para individu yang rasional memilih untuk mengikatkan

${ }^{36}$ Oman Sukmana, et.al., Negara Kesejabteraan dan Pelayanan Sosial: Kebijakan Sosial dan Pekerjaan Sosial dalam Penyelenggaraan Jaminan Perlindungan Warga Negara, Intrans Publishing, Malang, 2015, hlm. 18.

${ }^{37}$ Ibid., hlm. 102.

38 Anthony Gidden, Left and Right: Tarian Ideologi Alternatif di atas Pusaran Sosialisme dan Kapitalisme, Dikutip dari Oman Sukmana, et.al., Negara ..., Op. Cit., hlm.10-11.

39 I.B. Wirawan, Teori-Teori Sosial dalam Tiga Paradigma: Fakta Sosial, Definisi Sosial dan Perilaku Sosial, Cetakan Pertama, Kencana, Jakarta, 2012, hlm. 61. 
diri pada situasi yang menghendaki terwujudnya suatu keadilan tersebut dan kemudian menegaskan dan memberikan konsep keadilan yang dimaksud. ${ }^{40}$

Keadilan dalam Islam mengajarkan agar dalam hidup bermasyarakat ditegakkan keadilan dan ihsan, adil dan ihsan di kalangan masyarakat muslim maupun umat manusia pada umumnya. Keadilan sosial juga wajib ditegakkan, keadilan sosial menuntut agar setiap individu anggota masyarakat terpenuhi hakhaknya, baik hak-hak jasmaniah maupun rohaniah, material maupun spriritual. ${ }^{41}$ Zakat memiliki posisi yang strategis dan menentukan bagi pembangunan kesejahteraan umat dan tujuan utama zakat yaitu mecapai keadilan sosial ekonomi. Zakat merupakan transfer sederhana dari bagian ukuran tertentu harta si kaya untuk dialokasikan kepada si miskin. ${ }^{42}$

Monzer Khaf mengatakan, bahwa zakat mengarah kepada distribusi harta yang egaliter dan sebagai akibat dari zakat maka harta akan selalu beredar. Zakat mengandung makna yang luas daripada sekedar pelaksanaan syariah Islam. Sisi ekonomi, zakat menghambat terjadinya penimbunan harta kekayaan yang menjadi sumber terjadinya kesenjangan sosial ekonomi dalam masyarakat dan sebaliknya zakat mendorong pertumbuhan investasi dan menggugah etos kerja umat. 43

Faktor atau kondisi yang menyebabkan terjadinya penurunan tingkat kesejahteraam orang perorang atau masyarakat sehingga pada akhirnya menjadi miskin harus diantisipasi dan ditanggualngi secara sistematis dan komprehensif melalui zakat dan ibadah sosial lainya sebagai wujud nyata komitmen umat Islam dan tentunya pemerintah yang berkewengan mengeluarkan kebijakan untuk mewujudkaan kesejahteraan masyarakat.

\section{Formulasi Pengelolaan Zakat di Indonesia}

Formulasi adalah merumuskan atau menyusun dalam bentuk yang tepat. ${ }^{44}$ Sedangkan pengelolaan zakat adalah kegiatan perencanaan, pelaksanaan dan pengkoordinasian dalam pengumpulan, pendistribusian dan pendayagunanaan zakat. ${ }^{45}$ Formulasi pengelolaan zakat dapat dipahami merumuskan pengelolaan

\footnotetext{
40 John Rawls, Teori Keadilan: Dasar-dasar Filsafat Politik untuk. Memujudkan Kesejahteraan Sosial dalam Negara, diterjemahkan oleh Uzair Fauzan, Heru Prasetyo, Cetakan Ketiga, Pustaka Pelajar, Yogyakarta, 2019, hlm. 16.

${ }^{41}$ Ahmad Azhar Basyir, Pokok-pokok Persoalan Filsafat Hukum Islam, Cetakan Kedua, UII Press, Yogyakarta 2011, hlm. 47.

42 Nurul Huda, et.al., Loc. Cit.

${ }^{43}$ Departemen Agama Republik Indonesia, Pedoman Pedoman Zakat 9 Seri, Bagian Proyek Peningkatan Zakat dan Wakaf Jakarta, Jakarta, 2002, hlm. 3.

44 https://kbbi.web.id/formulasi, diakses 8 Juni 2021, pukul 08.00 WIB.

45 Pasal 1 ayat (1) Undang-Undang Nomor 23 Tahun 2011, Lembaran Negara Tahun 2011 Nomor 115 tentang Pengelolaan Zakat.
} 
zakat dengan bentuk yang tepat untuk meningkatkan daya guna dan hasil guna untuk mengentaskan kemiskinan di Indonesia.

Zakat hadir bertujuan untuk meningkatkan keadilan dan kesejahteraan masyarakat. Dengan melihat jumlah umat Islam Indonesia yang mayoritas, tentunya ketika umat Islam mengeluarkan zakat maka potensinya sangatlah besar untuk meningkatkan keadilan dan kesejahteraan masyarakat. Pengumpulan zakat 2020 terkumpul Rp. 12.700.000.000.000,00 dan tersalurkan ke 4.400 .000 asnaf fakir miskin. ${ }^{46}$

Beik mengkategorikan pengelolaan zakat pada tipologi sistem perzakatan yang ditinjau dari regulasi dan kewajiban berzakat berdasarkan hukum positif. Tiga tipologi sistem perzakatan tersebut meliputi model pengelolaan zakat komprehensif, model pengelolaan parsial dan model pengelolaan sekuler. Model komprehensif didefinisikan sebagai model dimana suatu negara telah memiliki undang-undang dan peraturan formal tentang zakat dan telah menjadikan zakat sebagai kewajiban yang harus ditunaikan oleh warganya. Model pengelolaan zakat parsial, model ini merupakan model dimana suatu negara telah memiliki dasar hukum atau aturan formal yang mengatur perzakatan, namun belum menjadikan zakat sebagi kewajiban yang harus ditunaikan warga negara berdasarkan perspektif hukum positif. Model sekuler dimana negara menerapkan model ini merupakan negara yang menganggap bahwa zakat adalah urusan pribadi masyarakat sehingga tidak ada intervensi pemerintah maupun regulasi terhadap institusi zakat itu sendiri. ${ }^{47}$

Praktek pengelolaan zakat di Indonesia masuk dalam kategori model parsial atau valuntary system, dimana negara telah memiliki dasar hukum atau aturan formal yang mengatur perzakatan, namun belum menjadikan zakat sebagai kewajiban yang harus ditunaikan warga negara berdasarkan perspektif hukum positif. Adanya Undang-Undang Nomor 23 Tahun 2011 tentang Pengelolaan Zakat menjadi bukti keterlibatan negara dalam sistem pengelonaan zakat, dimana pengumpulan dan pendistribusian zakat dilakukan secara sukarela serta pengelolaan zakat dilakukan oleh pemerintah maupun masyarakat sipil. Secara yuridis-formal undang-undang ini hanya terbatas pada pengaturan pengelolaan zakat dan tidak memiliki kekuatan memaksa muzaki dalam membayarkan zakat. Supremasi pemerintah, selaku penguasa dan penyelenggara negara yang memiliki daya paksa dan hanya disebutkan bahwa petugas hanya akan mengambil zakat setelah diberitahu oleh muzaki. ${ }^{48}$

\footnotetext{
hlm. 39.

47 Irfan Syauqi Beik, et.al., Arsitektur Zakat Indonesia, Cetakan Pertama, Puskas BAZNAS, Jakarta, 2017, hlm. 13-15

48 Naskah Akademik Rancangan Undang-Undang Perubahan atas Undang-Undang Nomor 38 Tahun 1999 tentang Pengelolaan Zakat.
}

${ }^{46}$ Achmad Setio Adinugroho, Statistik. Zakat Nasional 2019, BAZNAS-Sub Divisi Pelaporan, Jakarta, 2020, 
Praktek pengelolaan zakat di Indonesia saat ini mengalami peningkatan kualitas pengeloaannya, dikelola transparan secara profesional, kemudahan, akses, kenyamanan, lingkungan dan kepuasan, mulai amil zakat, lembaga amil zakat sampai pada pendistibusian dana zakat. Salah satu bukti keberhasilannya adalah penggalangan dana zakat yang meningkat secara signifikan, pada 2006 dana zakat terkumpul sebesar Rp. 162.700.000.000,0049 dan pada 2020 terkumpul Rp. 12.273.000,000,000,0050 dengan pengumpulan yang bersifat sukarela. Bisa kita bayangkan ketika zakat diwajibkan bagi orang kaya sebagai orang wajib zakat, tentu dana zakat yang terkumpul akan lebih besar dan kesejahteraan umat/masyarakat meningkat serta menjadikan perubahan bagi mustahik berubah perannya menjadi muzaki.

\section{Penutup}

Berdasarkan uraian di atas, dapat disimpulkan sebagai berikut: pertama, politik hukum pengelolaan zakat di Indonesia yang melahirkan undang-undang tentang pengelolaan zakat di Indonesia gagal mendukung struktur zakat nasional yang mendorong akselerasi pengentasan kemiskinan dan peningkatan kesejahteraan serta berorientasi pada menjadikan orang yang berhak menerima zakat berubah menjadi orang yang berkewajiban membayar zakat berdasarkan meningkatnya dana zakat yang terkumpul. Kedua, sebaiknya formulasi Pengelolaan zakat masa yang akan datang di Indonesia, harapannya dikelola dengan Model Komprehensif. Sistem pembayaran zakat secara wajib, dimana peran negara dalam pengelolaan zakat dominan dan signifikan untuk mengimplementasikan zakat secara efektif dalam kehidupan masyarakat diperlukan suatu kekuatan yang memaksa dan mengatur. Negara memiliki kekuatan untuk memaksa dan mengatur ini.

\section{Daftar Pustaka}

\section{Buku}

Ali Hasan, M., Zakat dan Infak: Salah Satu Solusi Mengatasi Problema Sosial di Indonesia, Cetakan Ketiga, Prenamedia Group, Jakarta, 2015.

Al-Qardawi, Yusuf, Figh al-Zakah, Diterjemahkan oleh Salman Harun, Didin Hafidudin, Hasnudin. Cetakan Kedua Belas, Pustaka Litera Antar Nusa, Bogor, 2007.

Asshidiqie, Jimly, Konstitusi Ekonomi, Cetakan Kedua, Kompas, Jakarta, 2016.

\footnotetext{
49 Amelia Fauzia, Filantropi ..., Op. Cit., hlm. 246.

50 Achmad Setio Adinugroho, et.al., Loc. Cit.
} 
Azhar Basyir, Ahmad, Pokok-pokok Persoalan Filsafat Hukum Islam, Cetakan Kedua, UII Press, Yogyakarta, 2011.

Badan Pusat Statistik, Berita Resmi Statistik: Profil Kemiskinan di Indonesia Maret 2020, BPS, Jakarta, 2020.

Departemen Agama Republik Indonesia, Al-Qur'an dan Terjemahnya, diterjemahkan oleh Yayasan Penyelenggara Penterjemah Al-Qur'an, PT Intermasa, Jakarta, 2010.

Departemen Agama Republik Indonesia, Pedoman Zakat 9 Seri, Bagian Proyek Peningkatan Zakat dan Wakaf Jakarta, Jakarta, 2002.

Fauzia, Amelia, Filantropi Islam "Sejarah dan Kontestasi Masyarakat Sipil dan Negara di Indonesia", Gading Publishing, Yogyakarta, 2016.

Mahfud MD, Moh., Politik Hukum di Indonesia, Cetakan Kelima, Rajawali Pers, Jakarta 2012.

Mahmud Marzuki, Peter, Penelitian Hukum Edisi Revisi, Cetakan Ketujuh, KENCANA, Jakarta, 2015.

Rawls, John, Teori Keadilan: Dasar-dasar Filsafat Politik untuk Mewujudkan Kesejahteraan Sosial dalam Negara, diterjemahkan oleh Uzair Fauzan, Heru Prasetyo, Cetakan Ketiga, Pustaka Pelajar, Yogyakarta, 2019.

Rosadi, Otong, dan Andi Desmon, Studi Politik Hukum : Suatu Optik Ilmu Hukum, Thafa Media, Yogyakarta, 2013.

Setio Adinugroho, Achmad, Statistik Zakat Nasional 2019, BAZNAS-Sub Divisi Pelaporan, Jakarta, 2020.

Suadi, Amran dan Mardi Candra, Politik Hukum: Perspektif Hukum Perdata dan Pidana Islan serta Ekonomi Syari'ah, Cetakan Pertama, Kencana, Jakarta, 2016.

Sukmana, Oman, et.al., Negara Kesejahteraan dan Pelayanan Sosial: Kebijakan Sosial dan Pekerjaan Sosial dalam Penyelenggaraan Jaminan Perlindungan Warga Negara, Intrans Publishing, Malang, 2015.

Syauqi Beik, Irfan, et.al., Arsitektur Zakat Indonesia, Cetakan Pertama, Puskas BAZNAS, Jakarta, 2017.

Timorita Yulianti, Rahmani, Good Corporate Governance di Lembaga Zakat, Kaukaba Dipantara, Yogyakarta, 2015.

Wibisono, Yusuf, Mengelola Zakat Indonesia "Diskursus Pengelolaan Zakat Nasional dari Rezim Undang-Undang Nomor 38 Tahun 1999 ke Rezim Nomor 23 Tahun 2011 ", Prenadamedia Group, Jakarta, 2015.

Wirawan, I.B., Teori-Teori Sosial dalam Tiga Paradigma: Fakta Sosial, Definisi Sosial dan Perilaku Sosial, Cetakan Pertama, Kencana, Jakarta, 2012.

\section{Jurnal}

Firmansyah, "Zakat sebagai Instrumen Pengentasan Kemiskinan dan Kesenjangan Pendapatan", Jurnal Ekonomi dan Pembangunan, Vol. 21 No. 2, 2013. 


\section{Perundang-undangan}

Naskah Akademik Rancangan Undang-Undang Perubahan atas Undang-Undang Nomor 38 Tahun 1999 tentang Pengelolaan Zakat.

Indonesia, Undang-Undang Dasar 1945, Sinar Grafika, Jakarta, 2013.

Indonesia, Undang-Undang Nomor 23 Tahun 2011, Lembaran Negara Tahun 2011 Nomor 115 tentang Pengelolaan Zakat.

\section{Internet}

Agustianto, "Politik Hukum Ekonomi Syariah", dalam http:/ / www.agustiantocentre.com/?p=450, diakses 27 Agustus 2020, pkl 20.00 WIB.

https:/ / kbbi.web.id/formulasi, diakses 8 Juni 2021, pkl 08.00 WIB.

https:/ / kbbi.kemdikbud.go.id/entri/pengentasan, diakses 22 Mei 2021, pkl 21.48 WIB.

https: / / tirto.id/jokowi-bahas-tiga-program-pengentasan-kemiskinan-ctqT, diakses 7 Juni 2021, pkl 17.20 WIB. 